\title{
Investigating the Relationship of Spiritual Experiences and Hardiness withOccupational Stressamong Nurses in Zabol
}

\author{
Hossein Jenaabadi \\ Associate professor,department of education, university of Sistan and Baluchestan \\ hjenaabadi@ped.usb.ac.ir \\ Somaie Nakhaeei
}

MA of General Psychology,department of psychology, sistan and baluchestan science and research branch, Islamic Azad University, Zahedan,iran.

\begin{abstract}
Thepresent study aimedto investigate the relationship of spiritual experiences and hardiness with occupational stress among nurses. This is a descriptive-survey study. The research population consisted of nurses working as formal, contractual, provisional, andprojectemployees at hospitals of Zabol. The sample consisted of 173 nurses. Research instruments includedthe Spiritual ExperienceScale for Studentsdeveloped byGhobari-Bonab,Kobasa's Hardiness Questionnaire and the Expanded Nursing Stress Scale (ENSS). The content validity was checked and the reliability of these three questionnaires was estimated using the Cronbach's alpha coefficients. This coefficient for these three questionnaires was $0.75,0.76$, and 0.85 respectively. The Pearson correlation, stepwise regression, independent t-test, and one-way ANOVAwere used to analyze the obtained data. Results revealed that there was a negative significant relationshipamong spiritual experiences, hardiness andoccupational stress. Moreover,no significant relationship was found between organizational commitment and occupationalstress. However, it was revealed that there was a negative significant relationship between occupationalstress, control, and challenge. The findings alsoindicated thatamong the predictor variables of nurses' stress, in the first step thetranscendent experiences, in the second step prosperity, in the third step belief in God, in the fourth step negative experiences,and in the fifth step finding meaning in lifeenteredthe predictionmodel.
\end{abstract}

Keywords: Spiritual Experiences; Hardiness; OccupationalStress.

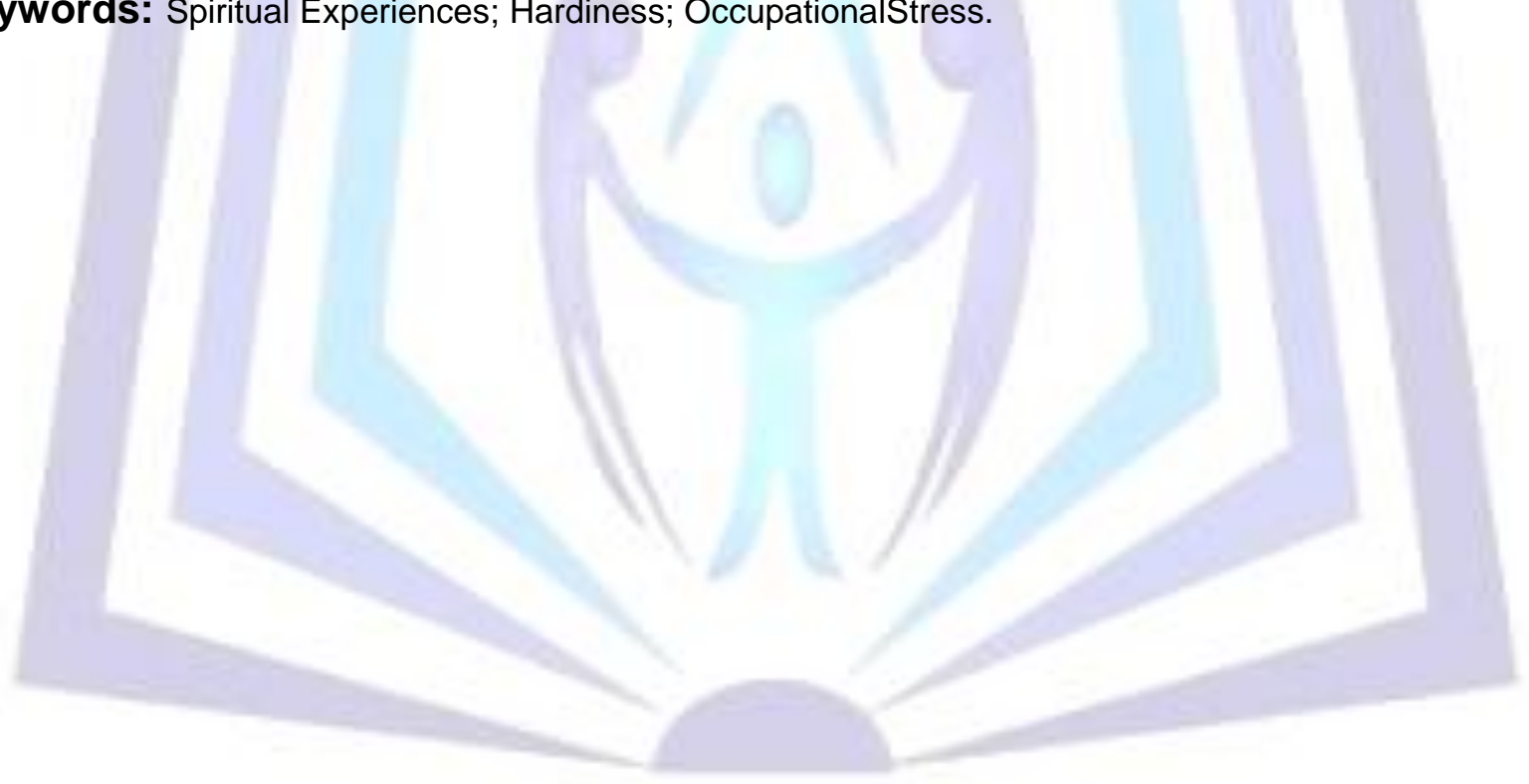

\section{Council for Innovative Research}

Peer Review Research Publishing System

Journal: Journal of Social Sciences Research

Vol. 5, No.1

jssreditor.cir@gmail.com

www.issronline.com 


\section{Introduction}

Since human being began to know himself, hehas sought endeavor and activity. Therefore,employment constitutes a major part of human life. However, one of the most important areas of development and promotion of health in societiesis the health sector that is directly associated with public health and among the jobsknown in this sector, nursingis especially considered as a significantoccupation (Madadi, 2003). It has been recognized that care providers'mental health may have a significant effect on care receivers and patients' health (Talaei, 2008). Recent research suggests an increasing growth of occupational depression and mental illness, especially depression and anxiety,among health workers, including nurses. Nurses, as health care providers, are required to meet patients' needs. This is only possible if nurses work 24 hours. Nursing requires different working shifts,compared to any other job, particularly night shifts. Studies have shown thatdue to stressors such as death of patients, providing care for patients with complex care needs, interpersonal problems, low social support, high workload, lack of job security, low wages and benefits, dealing with large number of patients during the day, emergency decisions based on insufficient information and accountability for the results of the decision, effortsalong with mental stress to avoid any confusion, facing violence and intimidation in the workplace, and night shifts watches, health workers compared to other jobs are more prone to further reducedoccupational performance and psychosocial problems which may affect their physical and mental health (Talaei, 2008). Several studies have attempted to discover the factorswhichhelp people with traumatic conditionsand preventthem from injury and destruction caused under heavy pressure of problems (Ghobari-Bonab, 2008). Nowadays,stressful experiences endanger individuals' mental health and cause psychological distress more than ever. Life in the industrialized world where human relationships and social support is faded, proper human relations are endangered and people have to effort continuously to live a life withoutconsidering theirhuman indigenous demands and needshas provided traumatic conditions for mental health and wellbeing of people including nurses (Ghorbani, 2004).Stress is an inseparable part of today's life. The contemporary human experiences the stress and suffers from its harmful effects wherever he/she is. Stress impresses different aspects of individuals' life including cognitive, emotional, mental and even physical aspects. Not only does stress affectthe individual, but also it torments organizations and professional environments with its complications, so that it causesthe occurrence ofrepeated absence and finally burnout. On the other hand, the advancement of technology in the present century and the rising machine life have deprived human from his own root. As a result, humanhas to reduce his attention to spiritual and emotional needs and is exposed to stress. Stress is among the factors that reduce productivity in professional and family environments. In the recent decade,stress has been considered as one of the major topics of organizational behavior.Mental pressure inthe office can have a negative and wide effect on individuals' health and their daily performance as well as their existential dimensions. Occupational mental pressure has no limit and affectswomen, men, executive managers, secretaries and so on and so forth. Only organizations canadapt to conditions that have employees withhighspiritual power. Therefore, some management theoristspropose the category of spirituality at work to cope withtoday's complex world changes. Thus, one of the concepts that have been proposed to developinghuman resourcesis spirituality at work. The definition used and emphasized in the present research study is definition provided by Isthmus as follows: "Spirituality at work environment is defined as the perception and identification of a dimension of an individual's work life which is internal and trainableand trained through performing meaningful tasks inthe social life". The introduction of concepts such as ethics, truth, belief inGod, integrity, conscience, magnanimity, trust, grace, forgiveness, amiability, consideration, spirituality at work, solidarity with colleagues, encouraging staffs, peace and altruism and ....into new research studies on management and organization, all confirm the above definition (Baezzat, et al., 2012). One of the variables, assessment of whichappearsto be logical toexplain the variability of orientation to anxiety, is hardiness. Kobasa (1996) introducedhardiness as a complex personality traitconsisting of three components, i.e., challenge, control, and commitment. An individual with high levels of challenge considers life events as opportunities for dynamism and re-adjustment and a field for research and self-promotion and does not passively choose to give up in such events. An individual with high levels of control has aninfluential feeling toward his/herself, considering himself/herself as a responsible and authoritative person toward the changes and transformations. An individual with high levels ofcommitment not only feels the eligibility of self-value, but also believes invaluable things which highlight the importance of life and the meaning of existence (Maddi, 1979).

The research question is that "what is the relationship of hardiness and spiritual experiences withoccupational stress among nurses?"

\section{Research Background}

Desrosiersand Miller (2007) also indicated asignificant relationship between daily spiritual experiences and the level of depression.

Studies carried out by Ganji and Hosseini (2010), Ghobari-Bonab et al. (2006) and Jalilvand (2004) have stressed the effectiveness and positive relationship of spirituality with reduction of depression and anxiety and enhancement of mental health.

Hills et al. (2005), investigating the relationship between anxiety and spirituality among thepatients of the outpatient department, concluded thatindividuals who expressed their anger to God orquestioned God (an example of negative coping) were more likely to develop anxiety and lived in obscurity. In addition, their quality of life was negatively affected by these negative copings.

The results of Aliani and Mahin's (2004) study conducted on 369 students showed that high degree of commitment to pray was associated with less anxiety. 
Mc Cllough, Haiet, Larson, Koenig andTorrson (2000), using a meta-analysis of 42 research reports, investigated the relationship of mortality rate and religious involvement. The researchers analyzed the research findings and concluded that religious involvement was significantly associated with less mortality rate. Studies also show that religiosity helps individuals to deal with stress in stressful situations.

Mann, Mckeown, Bacon, Vesselinorand Bush (2008), studying pregnant women, found that religion and spirituality play an essential role in reducing depression in pregnant women (as cited in Ghobari-Bonab,et al., 2009).

Hoart, et al. (2003) conducted a study on the relationship among hardiness, supervisor support, group cohesion, and occupational stress as predictors of job satisfaction among 160 full-time employees. The results indicated that high hardiness, supervisor support, and group cohesion were associated with low levels of occupational stress and this in turn was associated with high levels of job satisfaction.

Several studies (Collins, 1999; Judkins, 2002, Van Servellenand Leake, 1994; Wright Blace, Ralph and Lutermn,1994) investigated the relationship among the concepts of hardiness, personality, job burnout and stress among home nurses. The results showed that nurses with high levels of hardiness indicatedlower stresslevels and had high levels of job satisfaction.

Ghobari-Bonab (2009) conducted a research study on 304 students of Tehran University entitled "The Relationship of Anxiety and Depression with Levels of Spirituality among Tehran University Students". The results showed a negative correlation between anxiety and dimensions of spirituality and a positive correlation between depression, anxiety and negative spiritual experience. Also,the correlation between depression, finding meaning in life, relationship with God and spiritual prosperitywas negative. In terms of gender, anxiety and depression were higheramong women compared to men.

\section{Methods and Materials}

The research method was descriptive-correlational. The population of the study consisted of all nurses who worked as formal, contractual, provisional, and project employeesat hospitals of Zabol. The sample consisted of 173 nurses selected through simple random sampling method. Experimental data of the research were extracted through applying threequestionnaires as the main data collection instruments.

\section{Questionnaires}

A) The Spiritual Experience Scale for Students, developed by Ghobari-Bonab, used to measure spiritual experiences.

B) Kobasa's Hardiness Questionnaire used to measure hardiness.

C)The Expanded Nursing Stress Scale (ENSS) applied to measure occupational stress.

\section{Psychometric Characteristics of the Questionnaires}

In order to measure the reliability of the questionnaires, theCronbach's alpha coefficient was performed using SPSSsoftware v.21. The following table depicts the final results of the reliability test forthesethree scales.

Table 1: Alpha coefficient to determine the reliability of these three research scales

\begin{tabular}{|l|l|l|}
\hline & Variables & $\begin{array}{l}\text { The } \\
\text { Cronbach's } \\
\text { alpha }\end{array}$ \\
\hline 1 & $\begin{array}{l}\text { Spiritual } \\
\text { experiences }\end{array}$ & 75 \\
\hline 2 & $\begin{array}{l}\text { Occupational } \\
\text { Stress }\end{array}$ & 85.1 \\
\hline 3 & Hardiness & 75.6 \\
\hline
\end{tabular}

Using SPSS software program V.21 and conducting statistical tests including the Pearson correlation coefficient, stepwise regression, independent $t$-test, and one-way ANOVA, the research variables were analyzed.

\section{Data Analysis}

Question 1: Is there any significant relationship between spiritual experiences and occupational stress among nurses in Zabol?

Table 2:Results of correlation coefficient between spiritual experiences and occupational stress

\begin{tabular}{|l|l|}
\hline Variables & $\begin{array}{l}\text { Occupational } \\
\text { Stress }\end{array}$ \\
\hline
\end{tabular}




\begin{tabular}{|l|l|l|}
\hline $\begin{array}{l}\text { Spiritual } \\
\text { experiences }\end{array}$ & $\mathrm{R}$ & -0.278 \\
\cline { 2 - 3 } & Sig. & .000 \\
\hline
\end{tabular}

The results indicate that thecorrelation coefficient between spiritual experiences andoccupationalstress $(r=-0.278)$ is significant at $99 \%$ confidence level $(\mathrm{P}<0.01)$ andthat there is a negativesignificant relationship between spiritual experiences and occupational stress.

Question 2: Is there any significant relationship between hardiness and occupational stress among nurses in Zabol?

Table 3: Results of correlation occupational stress

The results indicate that the hardiness and occupational stress $(r$ confidence level $(P<0.01)$ and that relationship between hardiness and

\begin{tabular}{|l|l|l|}
\hline \multicolumn{2}{|l|}{ Variables } & Hardiness \\
\hline Occupational & $\mathrm{R}$ & -.231 \\
\cline { 2 - 3 } Stress & Sig. & .001 \\
\hline
\end{tabular}

coefficient between hardiness and

correlation coefficient between $=-0.231)$ is significant at $99 \%$ there is a negative significant occupational stress.

Question 3: Is there any significant relationship between occupational stress and commitment among nurses in Zabol?

Table 4:Results of correlation coefficient between occupational stress and commitment

\begin{tabular}{|l|l|l|}
\hline \multicolumn{2}{|l|}{ Variables } & Commitment \\
\hline \multirow{2}{*}{$\begin{array}{l}\text { occupational } \\
\text { Stress }\end{array}$} & $R$ & -0.128 \\
\cline { 2 - 3 } & Sig. & 0.093 \\
\hline
\end{tabular}

The results indicatethat the correlation coefficient between occupationalstress and commitment $(r=-0.12)$ is not significant at the confidence level of $95 \%(P>0.05)$.

Question 4: Is there any significant relationship between occupational stress and control among nurses in Zabol?

Table 5:Results of correlation coefficient between occupational stress and control

\begin{tabular}{|l|l|l|}
\hline \multicolumn{2}{|l|}{ Variables } & Control \\
\hline $\begin{array}{l}\text { Occupational } \\
\text { Stress }\end{array}$ & $R$ & - \\
& & ${ }_{*}$ \\
\cline { 2 - 3 } & Sig. & 0.04149 \\
\hline
\end{tabular}

The results indicate that the correlation coefficient between occupational stress and control $(r=-0.149)$ is significant at the confidence level of $95 \%(\mathrm{P}<0.05)$ and that there is a negative significant relationship between occupational stress and control.

Question 5: Is there any significant relationship between occupational stress and challenges among nurses in Zabol?

Table 6:Results of correlation coefficient between occupational stress and challenges

\begin{tabular}{|l|l|l|}
\hline \multicolumn{2}{|l|}{ Variables } & \multicolumn{1}{l|}{ Challenges } \\
\hline $\begin{array}{l}\text { occupational } \\
\text { Stress }\end{array}$ & $\mathrm{R}$ & $-.486^{* *}$ \\
\cline { 2 - 3 } & Sig. & .000 \\
\hline
\end{tabular}

The results indicate that the correlation coefficient between occupational stress and challenges $(r=-0.486)$ is significant at the confidence level of $99 \%(\mathrm{P}<0.01)$ and that there is a negative and reverse significantrelationship between occupationalstress and challenges.

Question 6: Can spiritual experience components predict the level of occupational stress among nurses in Zabol?

To measure the prediction level of nurses' job stress by spiritual experiencecomponents, regression analysis was used. The results are shown in the following table.

Table 7: Summary of the regression model of aspects of spiritual experiences to predict nurses' stress

\begin{tabular}{|l|l|l|l|l|l|l|}
\hline Step & Variable & $\mathrm{R}$ & $\mathrm{R}^{2}$ & $\beta$ & $\mathrm{t}$ & Sig \\
\hline
\end{tabular}




\begin{tabular}{|c|c|c|c|c|c|c|}
\hline 1 & $\begin{array}{l}\text { Transcendent } \\
\text { experiences }\end{array}$ & $.262^{\mathrm{a}}$ & 0.069 & 0.262 & 3.553 & .000 \\
\hline 2 & $\begin{array}{l}\text { Transcendent } \\
\text { experiences. + } \\
\text { Spiritual prosperity and } \\
\text { activity }\end{array}$ & $.448^{6}$ & .201 & $\begin{array}{l}0.874 \\
0.712\end{array}$ & $\begin{array}{l}6.511 \\
5.302\end{array}$ & .000 \\
\hline 3 & $\begin{array}{l}\text { Transcendent } \\
\text { experiences. + } \\
\text { Spiritual prosperity and } \\
\text { activity + } \\
\text { Relationship with God }\end{array}$ & $.510^{c}$ & 0.260 & $\begin{array}{l}0.744 \\
1.127 \\
0.585\end{array}$ & $\begin{array}{l}5.535 \\
6.557 \\
3.677\end{array}$ & .000 \\
\hline & $\begin{array}{l}\text { Transcendent } \\
\text { experiences. + } \\
\text { Spiritual prosperity and } \\
\text { activity + } \\
\text { Relationship with God + } \\
\text { Spiritually negative } \\
\text { experiences }\end{array}$ & $.577^{d}$ & 0.333 & $\begin{array}{l}0.884 \\
1.385 \\
0.673 \\
0.290\end{array}$ & $\begin{array}{l}6.691 \\
7.939 \\
4.405 \\
4.277\end{array}$ & .000 \\
\hline & $\begin{array}{l}\text { Transcendent } \\
\text { experiences + } \\
\text { Spiritual prosperity and } \\
\text { activity + } \\
\text { Relationship with God + } \\
\text { Spiritual negative } \\
\text { experiences + } \\
\text { Finding meaning in life }\end{array}$ & $.599^{\mathrm{e}}$ & 0.359 & $\begin{array}{l}0.807 \\
1.377 \\
0.736 \\
0.292 \\
0.166\end{array}$ & $\begin{array}{l}6.053 \\
8.021 \\
4.836 \\
4.376 \\
2.594\end{array}$ & .000 \\
\hline
\end{tabular}

The table indicates that investigating the predictor variables of stress among nurses, in the first step the transcendent experiences predicted $6 \%$ of occupational stress variations, and in the second step prosperity entered the model. These two variables predicted $20 \%$ ofoccupational stress variations. In the third step, belief in God entered the model. These three variables predicted $26 \%$ of occupational stress variations. In the fourth step, negative experiences enteredthe model, and these four variables predicted $33 \%$ of occupational stress variations. In the fifth step, finding meaning in life entered the prediction model. Overall, these five variables predict $35 \%$ of occupational stress variations.

\section{Conclusions}

Question 1: Is there any significant relationship between spiritual experiences and occupational stress among nurses in Zabol?

Results revealeda negative significant relationship between spiritual experiences and occupational stress. These findings are consistent with previous results ofGanji and Hosseini (2010), Bahrami Dashtaki et al. (2006) and Jalilvand (1383). They pointed out the effectiveness and positive relationship of spirituality with reduction of depression and anxiety and enhancement of mental health.

Question 2: Is there any significant relationship between hardiness and occupational stress among nurses in Zabol?

Results revealed that there was a negative a significant relationship between hardiness and occupationalstress, i.e., when hardiness (commitment, control and challenge) is high, occupational stress decreases. The findings are consistent withresearch studies conducted by Hoart (2003), Collins (1999) Judkins(2002), Van Servellenand Leake (1994), Wright Blace, Ralph and Luterman (1994) who concludedthat nurses with higher levels of hardiness have lower levels of stress. 
Question 3: Is there any significant relationship between occupational stress and commitment among nurses in Zabol?

Results revealed that there was no significant relationship between commitment and occupational stress.

Question 4: Is there any significant relationship between occupational stress and control among nurses in Zabol?

Results revealed a negative significant relationship between occupational stress and control, i.e., when the level of control is high, occupational stress decreases. The findings are consistent with the findings of previously conducte studies including the studies of Haart, et al. (2003) Collins (1999) Judkins (2002), Van Servellen and Leake (1994), Wright Blace, Ralph and Luterman (1994). Individuals with high levels of control believe that they are predictable and controllable in every situation. They believe that they have influence and can effectively cope with problems. In fact, control enhances one's ability to adjust to stressful situations. Therefore, it can be argued that such trait reduces occupational stress.

Question 5: Is there any significant relationship between occupational stress and challenges among nurses in Zabol?

Results revealed that there was a negative significant relationship between occupational stress and challenges, i.e., when the level of challenges is high, occupational stress decreases. The findings are consistent with the studies conducted by Haart, et al. (2003) Collins (1999) Judkins (2002), Van Servellen and Leake (1994), Wright Blace, Ralph and Luterman (1994).

Individuals with high levels of challenge consider the occurrence of changes and transformations as normal and ordinary affairs. They do not give up easily when encountering with life challenges. In fact, such a trait provides the basis for a better adaptation to different situations in life. It will also help individuals to have a more positive, better perception and higher degrees of satisfaction of work environment. Therefore, it could be argued that high levels of challenge can help individuals to decrease their occupational stress.

Question 6: Can spiritual experience components predict the level of occupational stress among nurses in Zabol?

It was also indicated that among the predictor variables of nurses' stress, in the first step the transcendent experiences, in the second step prosperity, in the third step belief in God, in the fourth step negative experiences, and in the fifth step finding meaning in life entered the prediction model. Overall. These five variables predict $35 \%$ of occupational stress variations.

\section{Reference}

1. Abdi, H., Kalani, Z., \& Harazi, M. (2000). Occupational stress among nurses. Journal of Medical Sciences and Health Services, Yazd, 8 (4), 17-21.

2. Aliani, Z. \& Mahin, H. (2004). Investigating the relationship between commitment to prayer and the level of anxiety in Tabari students. Paper presented at the $2^{\text {nd }}$ Seminar of Students' Mental Health, Tarbiat Moddares University in Tehran.

3. Baezzat, f. \& Sharifzadeh, H. (2012). The relationship of intellectual intelligence and emotional intelligence with occupational stress in university staffs. Psychological Research, 1(4): 27-37.

4. Ghobari-Bonab, B. (2008). Counseling and psychotherapy with a spiritual approach. Tehran: Publication Aaron.

5. Ghobari-Bonab, B., Salimi, M., Saliani, L., \& Nori moghaddam, S. (2006). Spiritual intelligence. Modern Religious Thought, 3(10), 125-147.

6. Ghorbani, N. (1995). Hardiness: personality structure. Psychological Research, 3.

7. Harrisson, M., Loiselle, C.G., Duquette, A., \& Semenic, S.E. (2002). Hardiness, work support and psychological distress among nursing assistants and registered nurses in Quebec. J Adv Nurs. 38(6), 584-91.

8. Hills, J., Paice, J. A., Cameron, J. R., \& Shot, S. (2005). Spirituality and distress in palliative care consultation. Journal of Palliative Medicine, 8(4), 782-788

9. Holmes S. (2001). Work related stress a brief review. Journal research social health, 121(4), 230-235.

10. James, W. (1961). The Varieties of Religious 'Experience, NY: Penguin.hinnells.( 1995). A New Dictionary of Religions, Oxford: Blackwell.

11. Jung, C. G. (1952). Symbols of Transformation: An Analysis of the Prelude to a Case of Schizophrenia. In Collected Works, Vol. 5 ( $2^{\text {nd }}$ ed.), 1967. (Fourth German edition 1952)

12. Koenig, H. G., Mc Cllough, M. E., \& Larson, D. B. (2001). Hand book of Religion and Health, New York, Oxford University Press.

13. Koenig, H.G., McCullough, M.E., \& Larson, D.B. (2001). Handbook of religion and health, Oxford, N. Y: Oxford University Press.

14. Kosaka, M. (1996). Relationship between hardiness and psychological stress response. Journal of Performance Studies, 65, 35-38.

15. Maddi, S., Khobasa, R., \& Zannec, S. (1979). The Hardy Executive: Health under.

16. Mann, J. R., Mckeown, R. E., Bacon, J., Vesselinor, R., \& Bush, F. (2008). Religiosity, spirituality, and antenatal anxiety in southern U.S. women. Archives of women's Mental Health. 11, 19-26.

17. Mi guel, B. A., Mary Joyce. C, Jordan. A. (2007). Common stressful situations and stress management practices among emergency room nurses in selected private hospitals in Marikina city. Bachelor of Science in Nursing. College of Nursing, AMA School of Medicine

18. Sancholi, M. (2007). Occupational stress (its nature, contributing factors and coping strategies). Center of Applied Sciences, Welfare Organization, Khorasan Razavi, Consulting Unit. 
19. Soltani, M., Amin olra'aia, M. \& Attari, A. (2008). The effects of stress management on female high school students' academic achievements in Tiran and Koron, Isfahan. Behavioral Research, 1, 9-16.

20. Taj, U.M. (2006). A study on the Quality of nurses of nurses of government hospitals in Bangladesh. Www.paspk.org/proc.

21. Talaei, A., Mokhber, N., Mohammad nejad, M. \& Samari, A. (2008). Occupational burnout and relating factors in staffs of hospitals of Mashhad University. Journal of Semnan University of Medical Sciences, 9(3(27)), 237-245.

22. Vogt, D.S., Rizvi, S.L., Shipherd, J.C., \& Resick, P.A. (2008). Longitudinal investigation of reciprocal relationship between stress reactions and hardiness. Pers Soc Psychol Bull. 34(1), 61-73. 